\title{
Ammonia-nitrogen turnover in the rabbit caecum and exchange with plasma urea- $N$
}

\author{
BY S. J. FORSYTHE* AND D. S. PARKER† \\ Department of Agricultural Biochemistry and Nutrition, University of \\ Newcastle upon Tyne, Newcastle upon Tyne NE1 7RU
}

(Received 28 November 1984 - Accepted 4 March 1985)

\footnotetext{
1. Continuous infusion and single-shot administration of ${ }^{15} \mathrm{NH}_{4} \mathrm{Cl}$ into the caecum of the conscious rabbit was used to measure caecal ammonia flux.

2. Continuous infusion of ${ }^{15} \mathrm{NH}_{4} \mathrm{Cl}$ and sampling from both the caecal ammonia and blood urea pools indicated that 0.27 of plasma urea-nitrogen was derived from caecal ammonia-N.

3. Values from intravenous $\left[{ }^{15} \mathrm{~N}\right] \mathrm{urea}$ and intracaecal ${ }^{16} \mathrm{NH}_{4} \mathrm{Cl}$ infusions were used to produce two models of the movement of $\mathrm{N}$ between these two metabolic pools.

4. Further analysis of the results suggested an alternative model involving a third pool associated with the caecal mucosa and values for this model are also presented.
}

In a previous study (Forsythe \& Parker, 1985a), plasma urea-nitrogen turnover rate and the proportion of urea degraded in the digestive tract of the rabbit were determined. Since the caecum has been shown to be the major site of urea hydrolysis in the rabbit gastrointestinal tract (Forsythe \& Parker, 1985a) it was decided to extend the previous work and study $\mathrm{N}$ exchange between plasma urea and caecal ammonia pools. Continuous infusions and single-shot administration of ${ }^{15} \mathrm{NH}_{4} \mathrm{Cl}$ were used to determine caecal ammonia- $\mathbf{N}$ irreversible loss rates (ILR) and transfer ratio of $\mathbf{N}$ to the plasma urea pool. ${ }^{15} \mathrm{~N}$ enrichment in the caecal ammonia pool was determined in the conscious animal on samples of caecal dialysate obtained using a caecal probe (Parker \& McMillan, 1976).

\section{MATERIALS AND METHODS}

\section{Animals and surgery}

New Zealand White and cross-bred Black and Brindle rabbits (2.4-3.5 kg body-weight) were purchased from a commercial source. They were maintained on a standard laboratory diet (141 $\mathrm{g}$ crude protein $(\mathrm{N} \times 6.25)$ and $155 \mathrm{~g}$ crude fibre $/ \mathrm{kg}$ ) which did not contain a coccidiostat. Feed and water were available at all times. General anaesthesia was induced with a gas mixture of Halothane (May \& Baker, Dagenham, Essex) in oxygen $(3: 97, \mathrm{v} / \mathrm{v})$ given through an open mask. All surgery was carried out under aseptic conditions. Implantation of the caecal probe, modified to include an infusion catheter, was carried out as previously reported (Parker \& McMillan, 1976) and, in addition, catheters were placed in a carotid artery and jugular vein (Jones \& Parker, 1978). Animals were eating normally within $4 \mathrm{~d}$ of the operation and infusion experiments were carried out over the following $10-14 \mathrm{~d}$ depending on the integrity of the dialysis tubing surrounding the probe.

\section{Isotope infusion and sample collection}

${ }^{15} \mathrm{NH}_{4} \mathrm{Cl}$ was continuously infused into the caecum $\left(290-990 \mu \mathrm{g}^{15} \mathrm{~N} / \mathrm{h}, 75.8\right.$ atoms $\%$ excess $)$ for $5-8 \mathrm{~h}$ or given as a single injection $\left(0 \cdot 5-4 \cdot 1 \mathrm{mg}{ }^{15} \mathrm{~N}\right)$ through the caecal infusion catheter.

* Present address: Department of Biochemistry, University of Birmingham, Birmingham, B15 2TT.

$\uparrow$ For reprints. 
During the infusion period the animals were restrained in a Perspex metabolism box with feed and water available at all times. Samples of arterial blood $(1 \mathrm{ml})$ were withdrawn into a heparinized syringe from the carotid artery at regular intervals. In addition, saline $(9 \mathrm{~g}$ sodium chloride $/ \mathrm{l})$ was pumped round the dialysis probe $(3 \mathrm{ml} / \mathrm{h})$ and dialysate collected continuously in $15 \mathrm{~min}$ fractions using a fraction collector. Following the isotope infusions, rabbits were returned to their cages and urine collected for $48 \mathrm{~h}$. The collecting tray contained sulphuric acid $(10 \mathrm{ml}, 500 \mathrm{ml} / \mathrm{l})$ to preserve the urine and prevent ammonia loss.

\section{Analytical methods}

Blood plasma and caecal dialysate were deproteinized by the method of Somogyi (1945). Samples for the measurement of ${ }^{15} \mathrm{~N}$ enrichment in urea or ammonia were pretreated using a modification of the Conway microdiffusion method. Urea- $\mathrm{N}$ was measured by treatment with urease $(E C 3.5 .1 .5 ; 2 \mathrm{mg} / \mathrm{ml}$ in $100 \mathrm{ml}$ glycerol $/ 1)$ for $1 \mathrm{~h}$ in the outer well of the unit and the ammonia evolved following the addition of saturated potassium carbonate trapped in hydrochloric acid $(6.66 \mathrm{~mm})$ in the centre well. Ammonia was liberated from caecal dialysate by the addition of saturated potassium carbonate and trapped as before. Ammonia concentration was determined by the method of Weatherburn (1967) in a portion of the solution and the remaining $\mathrm{NH}_{4} \mathrm{Cl}$ evaporated to dryness before ${ }^{15} \mathrm{~N}$ analysis was carried out by optical emission spectrometry using the method of Goulden \& Salter (1979). Samples of ${ }^{15} \mathrm{NH}_{4} \mathrm{Cl}$ were diluted immediately before analysis to enrichments of less than 8 atoms $\%$ excess and a $\mathrm{N}$ content of about $2 \mu \mathrm{g} \mathrm{N} / \mu \mathrm{l}$. Triplicate injections of $5 \mu \mathrm{l}$ were made for each sample and background abundance of the tracer determined by analysis of samples taken before the administraion of the ${ }^{15} \mathrm{NH}_{4} \mathrm{Cl}$.

\section{Mathematical analysis of isotopic values}

${ }^{15} \mathrm{~N}$ enrichment time-curves were analysed using the Maximum Likelihood Program (MLP, version 3.07, 1980; Rothamsted Experimental Research Station, Harpenden, Herts) to predict the plateau enrichment values. Two-pool and three-pool models of $\mathbf{N}$ exchange between blood urea and caecal ammonia were constructed using the equations of Depocas \& DeFreitas (1970) and Nolan et al. (1976).

\section{RESULTS}

Although ammonia concentration in caecal dialysate showed cyclical changes during the experimental periods studied (ranging from 1.0 to $1.35 \mathrm{~mm}$ ) this could not be ascribed to factors such as feeding behaviour and, since ammonia-N enrichment came to a plateau value during the infusion period, it was assumed that the variation in caecal ammonia concentration was due to changes in caecal volume or osmolarity rather than ammonia synthesis rate. Caecal ammonia-N ILR was determined in nine rabbits during continuous infusion of ${ }^{15} \mathrm{NH}_{4} \mathrm{Cl}$. The caecal ammonia- $\mathrm{N}$ enrichment reached a plateau value within $7 \mathrm{~h}$ of the start of the infusion and was analysed as a single rising exponential. Secondary labelling of plasma urea-N was detected within $1 \mathrm{~h}$ of the start of the infusion and did not reach a plateau value during the sampling period (Fig. 1). The mean value for caecal ammonia ILR was 25.3 (SE 2.5 ) $\mathrm{mg} \mathrm{N} / \mathrm{h}$ and the mean contribution of caecal ammonia-N to plasma urea-N calculated from the plateau enrichment values for caecal ammonia- $\mathrm{N}$ and plasma urea-N was 0.27 (SE 0.04) (Table 1). Due to the difficulties experienced in determining urea enrichment in urine accurately from these experiments it was only possible to obtain values for the proportion of the ${ }^{15} \mathrm{~N}$ dose infused into the caecum that was excreted in the urine in five of the nine infusions. The mean value for the proportion of the dose that was excreted in this way was $0 \cdot 18$ (SE 0.06) (Table 1 ). 


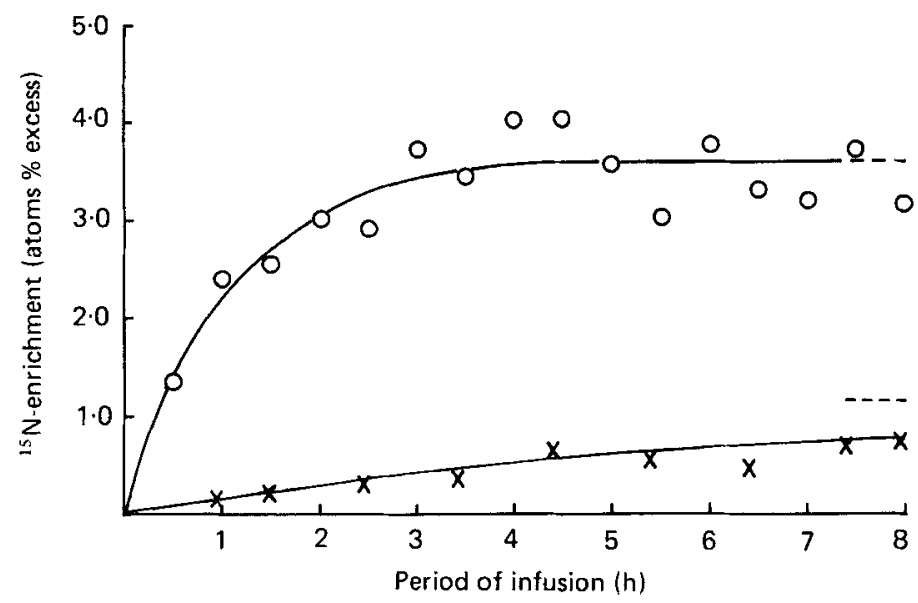

Fig. 1. Time-course of ${ }^{15} \mathrm{~N}$ enrichment (atoms $\%$ excess) of caecal dialysate ammonia- $\mathrm{N}(\mathrm{O})$ and plasma urea- $\mathrm{N}(x)$ during continuous intracaecal infusion of ${ }^{15} \mathrm{NH}_{4} \mathrm{Cl}(988 \mu \mathrm{g} \mathrm{N} / \mathrm{h})$ in a rabbit. (---), Plateau enrichment value determined from analysis of curve as a single exponential fitted to the equation: $Y=A+B \mathrm{e}^{-k t}$, where for caecal dialysate ammonia-N, $A$ is 3.54 (SE 0.113 ), $B$ is -3.56 (SE 0.327 ) and $k$ is 1.03 (SE 0.198); and for plasma urea-N, $A$ is 1.28 (SE 1.13), $B$ is -1.23 (SE 1.03) and $k$ is 0.101 (SE $0 \cdot 147) ; t$ is time.

Table 1. Caecal ammonia-nitrogen irreversible loss rate $(I L R)$, the proportion of plasma urea- $N$ derived from caecal ammonia- $\mathrm{N}$ and the proportion of the ${ }^{15} \mathrm{NH}_{4} \mathrm{Cl}$ dose recovered in the urine of rabbits in which ${ }^{15} \mathrm{NH}_{4} \mathrm{Cl}$ was continuously infused into the caecum

\begin{tabular}{lccc}
\hline \hline Rabbit & $\begin{array}{c}\text { Caecal ammonia-N } \\
\text { ILR (mg N/h) }\end{array}$ & $\begin{array}{c}\text { Proportion of plasma } \\
\text { urea-N derived from } \\
\text { caecal ammonia-N }\end{array}$ & $\begin{array}{c}\text { Proportion of } \\
\text { dose recovered } \\
\text { in urine }\end{array}$ \\
\hline NT17 & $21 \cdot 5$ & nd & $0 \cdot 03$ \\
NT20 & $24 \cdot 4$ & $0 \cdot 34$ & $0 \cdot 20$ \\
NT21 & $17 \cdot 9$ & $0 \cdot 30$ & $0 \cdot 31$ \\
NT26 & $21 \cdot 3$ & $0 \cdot 36$ & $0 \cdot 37$ \\
NT27 & $24 \cdot 7$ & $0 \cdot 13$ & $0 \cdot 19$ \\
NT33 & $19 \cdot 0$ & $0 \cdot 14$ & nd \\
NT34 & $42 \cdot 3$ & nd & nd \\
NT35 & $25 \cdot 2$ & $0 \cdot 34$ & nd \\
NT40 & $31 \cdot 5$ & nd & nd \\
Mean & $25 \cdot 3$ & $0 \cdot 27$ & $0 \cdot 18$ \\
SE & $2 \cdot 5$ & 0.04 & $0 \cdot 06$ \\
\hline
\end{tabular}

nd, not determined.

The caecal ${ }^{15} \mathrm{~N}$-ammonia decay curve following a single injection of ${ }^{15} \mathrm{NH}_{4} \mathrm{Cl}$ was in the form of a double exponential (Fig. 2) with an initial very rapid component followed by a slower one. These two components could not be resolved by the curve-fitting program used and the area-under-the-curve was determined gravimetrically. The inability of the MLP program to resolve the two exponents was probably due to insufficient data being available for the primary rapid component, as there was a maximum of four dialysate samples collected every hour. In addition, a further 3 or $4 \mathrm{~h}$ of sample collection would have been necessary to define the final portion of the curve. The flux rate obtained from the gravimetric determination and a knowledge of the original dose of isotope (flux $=$ (dose injected/area 


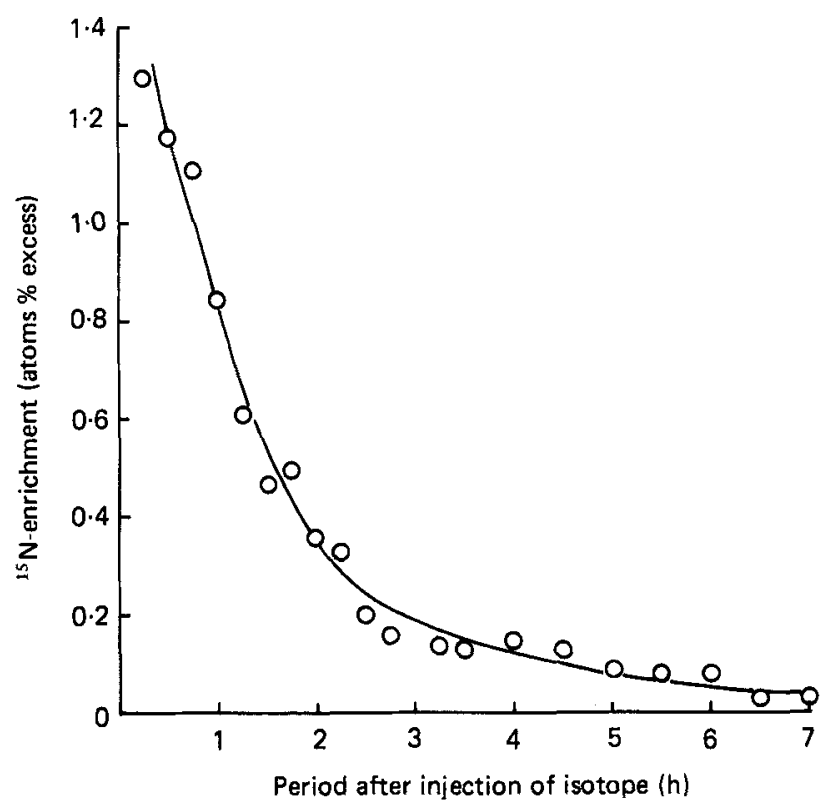

Fig. 2. Time-course of ${ }^{15} \mathrm{~N}$ enrichment (atoms \% excess) of caecal dialysate ammonia-N $(\mathrm{O})$ in a rabbit following a single injection of ${ }^{15} \mathrm{NH}_{4} \mathrm{Cl}$ at zero time.

Table 2. Caecal ammonia-nitrogen irreversible loss rate (ILR) following a single injection of ${ }^{15} \mathrm{NH}_{4} \mathrm{Cl}$ into the caecum of rabbits

\begin{tabular}{lc}
\hline \hline Rabbit & $\begin{array}{c}\text { Caecal ammonia-N } \\
\text { ILR (mg N/h) }\end{array}$ \\
\hline NT6 & $29 \cdot 4$ \\
NT31 & $24 \cdot 7$ \\
NT32 & $16 \cdot 1$ \\
NT37 & $12 \cdot 9$ \\
Mean & $20 \cdot 7$ \\
SE & $3 \cdot 8$ \\
\hline
\end{tabular}

under curve)) was interpreted as the caecal ammonia-N ILR rather than ammonia synthesis rate (based on the primary exponent) and recycling rate (based on the secondary exponent). The ammonia-N ILR calculated in this way following isotope administration to four animals was $20 \cdot 7$ (SE 3.8) $\mathrm{mg} \mathrm{N} / \mathrm{h}$ (Table 2).

Using values for plasma urea- $\mathrm{N}$ and caecal ammonia- $\mathrm{N}$ kinetics determined in the present study and in previous ones (Forsythe et al. 1983; Forsythe \& Parker, 1985a), it was possible to construct two-pool models of $\mathrm{N}$ flux between caecal ammonia- $\mathrm{N}$ and plasma urea- $\mathrm{N}$. Model 1 (Fig. 3(a)) was derived using values from four rabbits which had received ${ }^{15} \mathrm{~N}$ infusions into both plasma urea- $\mathrm{N}$ and caecal ammonia- $\mathrm{N}$ pools with sampling from primary and secondary pools. The model demonstrates a net flux of $\mathrm{N}$ from the caecal ammonia- $\mathrm{N}$ pool to the plasma urea-N pool of $4.6 \mathrm{mg} \mathrm{N} / \mathrm{h}$. The difference between the exchange rates, i.e. net flux between the two pools for the four individual models, was analysed by Student's $t$ test and was significant $(P<0.01)$. 
(a)

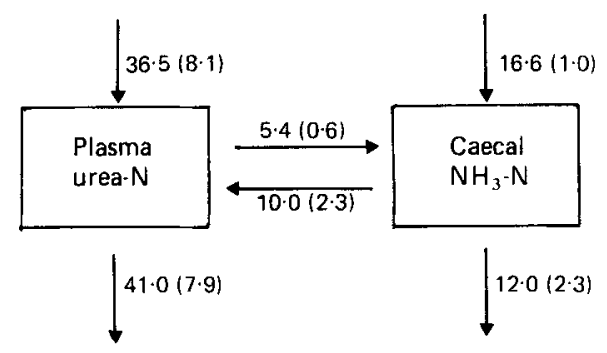

(b)

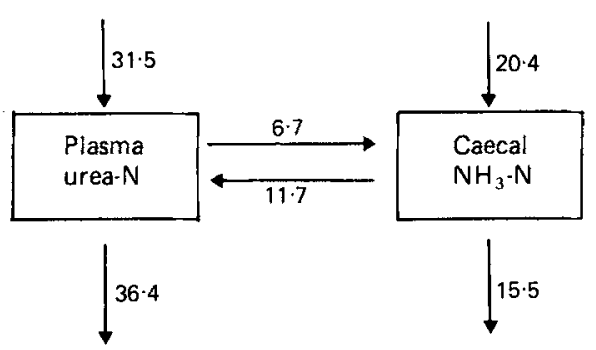

Fig. 3. (a) Two-pool model of nitrogen transactions between plasma urea-N pool and caecal ammonia- $\mathbf{N}$ pool in four rabbits which had continuous infusion of ${ }^{15} \mathrm{~N}$ tracer into both the blood urea and caecal ammonia pools. Rates expressed as $\mathrm{mg} \mathrm{N} / \mathrm{h}$ (with standard errors between animals). (b) Two-pool model of $\mathrm{N}$ transactions between plasma urea- $\mathrm{N}$ pool and caecal ammonia- $\mathrm{N}$ pool in thirteen rabbits which had received ${ }^{15} \mathrm{~N}$ tracer infusions into one or both of the pools and in which samples had been obtained from the primary pool and in some cases also from the secondary pool. Rates expressed as $\mathrm{mg} N / \mathrm{h}$.

A second two-pool model (Fig. 3(b)) of $\mathrm{N}$ flux through the plasma urea- $\mathrm{N}$ and caecal ammonia- $\mathrm{N}$ pools was derived from values from thirteen rabbits, four of which had only received $\left[{ }^{15} \mathrm{~N}\right]$ urea intravenously and five had only been infused with ${ }^{15} \mathrm{NH}_{4} \mathrm{Cl}$ intracaecally. In all cases the secondary pool had been sampled when possible. This second two-pool model using the mean ammonia-N and urea-N ILR values and transfer rates gave almost identical results to those provided by the paired values (Fig. 3(a)). The second model (Fig. 3(b)) predicted a net flux of $\mathrm{N}$ from the caecal ammonia- $\mathrm{N}$ pool to the plasma urea- $\mathrm{N}$ pool of $5.0 \mathrm{mg} \mathrm{N} / \mathrm{h}$.

\section{DISCUSSION}

The short time-period for infusion required to reach plateau enrichment during continuous infusion of ${ }^{15} \mathrm{NH}_{4} \mathrm{Cl}$ into the caecum and the rapid primary exponent of the decay curve following single-shot administration of isotope (Figs. 1 and 2) demonstrated the high flux rate of ammonia- $\mathrm{N}$ in the rabbit caecum $\left(24 \mathrm{mg} \mathrm{N} / \mathrm{h}\right.$ ). The second exponent of the ${ }^{15} \mathrm{NH}_{3}$ decay curve (Fig. 2) following single injection of isotope was probably ${ }^{15} \mathrm{~N}$ recycled to the caecal ammonia- $\mathbf{N}$ pool from labelled microbial $\mathbf{N}$ due to bacterial lysis and also endogenous urea- $\mathrm{N}$ recycled through the digestive tract. The enrichment with time-curve for caecal ammonia- $\mathrm{N}$ during continuous infusion of ${ }^{15} \mathrm{~N}$ isotope was fitted to a single rising exponential, not a double exponential as suggested by the single-shot values. The turnover 


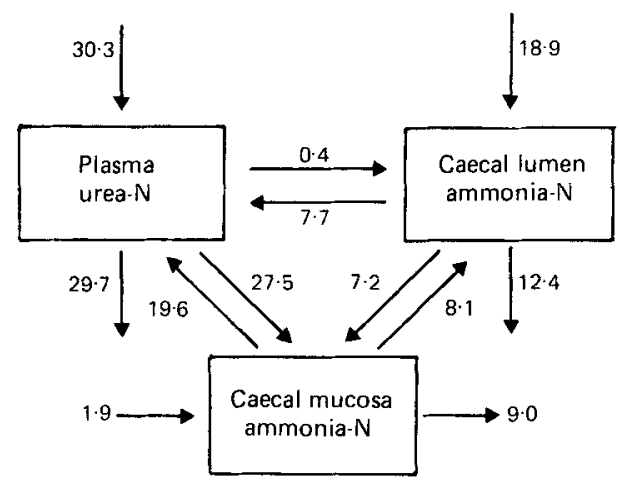

Fig. 4. Three-pool model of nitrogen transfer between plasma urea- $\mathrm{N}$, caecal lumen ammonia-N and caecal mucosa ammonia- $\mathrm{N}$ pools in the rabbit. Rates expressed in $\mathrm{mg} N / \mathrm{h}$ and the model derived from equations based on those reported by Nolan et al. (1976).

of the caecal ammonia- $\mathrm{N}$ pool and recycling of caecal ammonia- $\mathrm{N}$ was so rapid that during continuous administration of isotope only the first $30 \mathrm{~min}$ of caecal dialysate collection (two samples) would have been possible before substantial recycling of isotope occurred.

In the present study, caecal ammonia-N ILR was calculated as $13 \mathrm{mg} \mathrm{N} / \mathrm{h}$ per $\mathrm{kg}$ body-weight (BW) ${ }^{0.75}$ in the rabbit and this may be compared with values obtained in the caecum of sheep fed on lucerne (Medicago sativa) hay (13 mg N/h per $\mathrm{kg} \mathrm{BW}^{0 \cdot 75}$, Nolan et al. $1976 ; 9 \cdot 8 \mathrm{mg} \mathrm{N} / \mathrm{h}$ per kg BW ${ }^{0.75}$, Dixon \& Nolan, 1983) or bromegrass (Bromus inermis) $\left(2.9 \mathrm{mg} \mathrm{N} / \mathrm{h}\right.$ per $\mathrm{kg} \mathrm{BW}{ }^{0.75}$, Dixon \& Milligan 1984). The proportion of plasma urea-N derived from caecal ammonia- $\mathrm{N}$ in the rabbit $(0.27)$ was higher than the contribution of caecal ammonia- $\mathrm{N}$ to plasma urea- $\mathrm{N}$ in the sheep $(0 \cdot 13$, Nolan et al. (1976); $0 \cdot 14$, Dixon \& Nolan (1983); 0.10, Dixon \& Milligan (1984)). The rabbit two-pool model resembled the two-pool model for the sheep rumen in that there was a net flow of $\mathrm{N}$ into the plasma urea pool (Nolan et al. 1976). In the sheep experiments the net flux of $\mathrm{N}$ in the caecum was also from the caecal-N pool into the blood and, more recently, two eight-pool models of $\mathrm{N}$ kinetics in the sheep large intestine confirm this (Dixon \& Nolan, 1983; Dixon \& Milligan, 1984). Following ${ }^{15} \mathrm{NH}_{4} \mathrm{Cl}$ infusion into the caecum of the rabbit a significant proportion of the dose (0.8 approximately) was not excreted into the urine. This fraction represents the utilization of caecal ammonia- $\mathrm{N}$ for microbial- $\mathrm{N}$ synthesis, ammonia- $\mathrm{N}$ lost from the pool in the form of faecal ammonia- $\mathrm{N}$, tissue incorporation of amino acids synthesized in the liver from absorbed caecal ammonia and urea- $\mathrm{N}$ derived from caecal ammonia- $\mathrm{N}$ and subsequently recycled to the digestive tract. The tissue amino acid pool would act as a $\mathbf{N}$ sink during the sampling period as there would be negligible recycling from these metabolites to the caecal ammonia-N pool during this period (Nolan et al. 1976). It was also considered that the sample collection period used in the present experiment was too short for substantial recycling to the caecal ammonia-N pool of ${ }^{15} \mathrm{~N}$ from digested microbial-N due to coprophagy.

A proportion $(0.25)$ of caecal ammonia- $\mathrm{N}$ has been shown to be derived from plasma urea-N (Forsythe \& Parker, 1985a) and this value for the rabbit may be compared with values for the proportion of rumen ammonia- $\mathrm{N}(0.11)$ and caecal ammonia- $\mathrm{N}(0.32)$ derived from plasma urea-N in the sheep (Nolan et al. 1976). More recent studies of sheep on two different diets indicated that the proportion of caecal ammonia- $\mathrm{N}$ that was derived from plasma urea varied from 0.09 to 0.23 depending on metabolic activity within the caecum 
(Dixon \& Nolan, 1983; Dixon \& Milligan, 1984). If plasma urea represents only 0.25 of the caecal ammonia-N ILR, the proportion of caecal ammonia- $\mathrm{N}$ derived from non-urea $\mathrm{N}$ sources would be 0.75 or $18.9 \mathrm{mg} \mathrm{N} / \mathrm{h}$. This component would include undigested dietary $\mathrm{N}$ and endogenous $\mathbf{N}$ secreted into the gastrointestinal tract although the relative contributions of these components could not be determined quantitatively in these experiments.

Although the caecum is considered to be the major site of urea degradation in the rabbit, ${ }^{15} \mathrm{~N}$ and ${ }^{14} \mathrm{C}$ tracer studies could account for only 0.25 of the urea degradation rate as entering the caecal ammonia-N pool (Forsythe \& Parker, 1985a). Additionally, the rate of urea- $\mathrm{N}$ re-utilization $(19 \mathrm{mg}$ urea- $\mathrm{N} / \mathrm{h}$, calculated as the difference in plasma urea ILR determination using ${ }^{14} \mathrm{C}$ and ${ }^{15} \mathrm{~N}$ tracers) was substantially greater than the rate of caecal ammonia- $\mathrm{N}$ derived from urea- $\mathrm{N}$ which entered the plasma urea-N pool $(3 \mathrm{mg} \mathrm{N} / \mathrm{h})$. Although this could be ascribed to problems with mixing of isotope in the caecal pool sampled by the dialysis probe, it was considered that a more likely explanation was that there may be a second ammonia- $\mathrm{N}$ pool in the caecum as suggested by Wrong \& Vince (1984). This pool would consist of ammonia- $\mathrm{N}$ derived from plasma urea- $\mathrm{N}$ which mixes more rapidly with plasma $\mathrm{N}$ pools than with caecal ammonia, and may be envisaged as being associated with the caecal mucosa. A population of bacteria which exhibits urease activity has been shown to be adherent to the mucosal tissue of the rabbit caecum (Forsythe \& Parker, 1985b) and, on this basis, an open three-pool model of $\mathrm{N}$ flux (Nolan et al. 1976) was derived using values from both ${ }^{14} \mathrm{C}$ and ${ }^{15} \mathrm{~N}$ studies in rabbits. This procedure relies on developing equations which provide a range of values for unknown indices which in this case were the transfer ratios between the hypothesized mucosal ammonia pool and blood and caecal-N pools, and also the rate of mucosal ammonia-N ILR. These values were used to solve the three-pool model equations and the model which provided the best representation of the hypothesized $\mathrm{N}$ flux between the three pools is represented here. This model (Fig. 4) demonstrates a rapid flux of $\mathrm{N}$ between the caecal and mucosal ammonia- $\mathrm{N}$ pools and plasma urea- $\mathrm{N}$ pool and a less-rapid flux between the mucosa ammonia- $\mathrm{N}$ and caecal lumen ammonia-N pools. The majority of the flux of plasma urea- $\mathrm{N}$ into the caecal lumen ammonia pool came from the mucosal ammonia-N pool rather than directly from the plasma pool. There was a net flux of $\mathrm{N}$ from the caecal lumen ammonia- $\mathrm{N}$ pool to plasma urea-N of $7.3 \mathrm{mg} \mathrm{N} / \mathrm{h}$. The $\mathrm{N}$ which left the caecal ammonia-N pools but did not enter the plasma urea-N pool $(21.4 \mathrm{mg} \mathrm{N} / \mathrm{h})$ represents the utilization of ammonia- $\mathrm{N}$ for microbial- $\mathrm{N}$ synthesis, hepatic synthesis of amino acids and, to a lesser extent, ammonia- $\mathrm{N}$ lost from the caecum as faecal ammonia $(0.3 \mathrm{mg} \mathrm{N} / \mathrm{h}$ approximately). The three-pool model, in contrast to the two-pool models, demonstrated a net loss of $\mathrm{N}(0.6 \mathrm{mg} \mathrm{N} / \mathrm{h})$ from the plasma urea pool to the caecal ammonia pool.

In the series of experiments reported there was no direct method of sampling that would have ellucidated further information about the proposed three-pool model. Simultaneous measurement of portal vein ammonia-N, caecal dialysate ammonia-N and plasma urea-N enrichment would, however, allow for testing of the hypothesis of a mucosal ammonia-N pool. During the intravenous infusion of $\left[{ }^{15} \mathrm{~N}\right]$ urea the model would predict a greater enrichment of ${ }^{15} \mathrm{~N}$ in portal vein ammonia- $\mathrm{N}$ compared with caecal dialysate ammonia- $\mathrm{N}$ at any time during the infusion. Infusion of ${ }^{15} \mathrm{NH}_{4}$ into the caecum should result in lower enrichment in portal ammonia- $\mathrm{N}$ relative to caecal ammonia- $\mathrm{N}$ at any time during the infusion period. The values presented from the current study provide further evidence of the relation between plasma urea turnover and $\mathrm{N}$ movement into the intestine. In agreement with other studies in sheep (Dixon \& Nolan, 1983; Dixon \& Milligan, 1984) and man (Wrong \& Vince, 1984) it was apparent that urea- $\mathrm{N}$ degradation in the gastrointestinal tract may make little quantitative contribution to overall ammonia flux within the gut and that the 
relation between mucosal urea hydrolysis and flux of ammonia from the mucosal surface of the intestine may be critical in determining the extent to which blood urea is degraded in the intestine.

The authors are grateful to Dr D. N. Salter at the National Institute for Research in Dairying for allowing access to the emission spectrometer for $\mathrm{N}$ analysis and to $\mathrm{Mr}$ I. Montgomery for his technical assistance. This work was supported by the SERC and The University of Newcastle upon Tyne Research Board.

\section{REFERENCES}

Depocas, F. \& DeFreitas, A. S. W. (1970). Canadian Journal of Physiology and Pharmacology 48, 557-560.

Dixon, R. M. \& Milligan, L. P. (1984). Canadian Journal of Animal Science 64, 103-111.

Dixon, R. M. \& Nolan, J. V. (1983). British Journal of Nutrition 50, 757-768.

Forsythe, S. J. \& Parker, D. S. (1985a). British Journal of Nutrition 53, 183-190.

Forsythe, S. J. \& Parker, D. S. (1985b). Journal of Applied Bacteriology 58, 363-369.

Forsythe, S. J., Parker, D. S., Montgomery, I. \& Salter, D. N. (1983). Proceedings of the IV International

Symposium on Protein Metabolism. European Association for Animal Production, Publication no. 31, pp. $347-350$.

Goulden, J. D. S. \& Salter, D. N. (1979). Analyst, London 104, 756-765.

Jones, C. S. \& Parker, D. S. (1978). Biochemical Journal 174, 291-296.

Nolan, J. V., Norton, B. W. \& Leng, R. A. (1976). British Journal of Nutrition 35, 127-147.

Parker, D. S. \& McMillan, R. T. (1976). British Journal of Nutrition 35, 365-371.

Somogyi, M. (1945). Journal of Biological Chemistry 16, 69-73.

Weatherburn, M. W. (1967), Analytical Chemistry 39, 971-974.

Wrong, O. M. \& Vince, A. (1984). Proceedings of the Nutrition Society 43, 77-86. 